\title{
Gene therapy network sets industrial mould
}

Paris. The French/US pharmaceutical company Rhône-Poulenc Rorer (RPR) has announced an ambitious plan to create a new form of industrial organization for commercializing gene therapy through a coordinated network of academic research groups and biotechnology companies.

The company's plan is to use its network to access the many different technologies needed for such therapy. Biotechnology analysts have enthusiastically welcomed the move, arguing that a network approach may be more appropriate for gene therapy than either the traditional approach to drug research in big companies, or the US model of biotechnology start-ups.

Last year RPR took a 38 per cent stake in Applied Immune Sciences, a California genetherapy company. It followed this by regrouping its biotechnology activities into a single division focused on gene therapy, Biotech (see Nature 369, 92; 1994).

The new division, Gencell, will enlarge Biotech to involve a consortium of 14 academic groups and biotechnology companies. Thierry Soursac, senior vice-president of RPR and head of Gencell, says the idea is to "get one foot" in each of the technologies needed to commercialize gene therapy.

"The winners in gene therapy will not be those with the genes, but those who can deliver the product," says Peter Smith of the London stockbrokers James Capel. "It's different to a pill in the bottle, and more like the diagnostics industry."

Rachel Leheny, an analyst at Hambrecht \& Quist in New York, says that while many companies are pushing ahead in cell therapy, genomics and gene therapy, RPR appears to be the first to try to "straddle" all three areas. Most of the present gene-therapy and genomics partnerships are "missing a part of the puzzle", she says; in contrast, RPR has taken strategic alliances a step further "by going for a coordinated approach".

"If Gencell has all the parts to deliver genes, it will also be an attractive partner for genomic companies," says Smith.

It is also spreading its net wide. In gene sequencing, for example, Gencell has formed a Cooperative Research and Development Agreement (CRADA) with the Lawrence Berkeley Human Genome Center in California to access genes for the treatment of diabetes, obesity, cardiovascular diseases and nervous disorders.

Gencell includes links (through RPR's recent equity stake) to Darwin Molecular, the genome company based in Seattle, Washington, and to the French company Généthon. It also has access to each of the current classes of vector through the Université Louis Pasteur and the biotechnology company Transgène - both based in Strasbourg, France - and groups at the Centre National de la Recherche Scientifique
(CNRS), Introgen Therapeutics and Applied Immune Sciences.

In practice, scientists from the members of the consortium will sit on programme boards within Gencell to develop therapeutic projects. Royalties will be agreed in advance; for example, ownership of a gene will bring royalties of 6 to 10 per cent on sales, and a vector will bring 5 per cent.

Soursac argues that "it's a joke that large drug companies think they can automatically handle clinical trials in gene therapy the same way they do traditional drugs". He says that drugs come through trials either "dead or alive", but genes will go backward and forwards with progressive modifications, for example, to vectors or regulatory sequences. "Speed and success will depend on having the players and competencies close to hand," he says.

But while analysts are enthusiastic about RPR's general approach, they are more cautious about its own chances of success. One concern is that the arrangement is 'loose', in that RPR is only financing research programmes and has held back from the big outlay needed to buy equity stakes or obtain exclusive deals. "They are getting young companies desperate for cash," says one critic. "Medium-sized companies are talking to RPR, but they are not going to settle for only US\$5 million up-front."

But Soursac argues that gene therapy is a "moving target", and that it is "too soon and too risky" to take majority stakes in companies. "I'm not paying more than $\$ 5$ million up-front, plus milestone payments," he says. "When the time comes I will decide whether to grab or not." Soursac will seek new partners and eventually take majority stakes in members of the network "at market prices".

Soursac also says, for example, that the Lawrence Berkeley Human Genome Center could have found a more attractive financial deal than his, but that its director, Edward Rubin, was attracted by the concept of Gencell. "He was more interested in the network, the technology base and the quality of scientists than the money," says Soursac.

Indeed, the magic spell of Bill Gates, chief executive officer of Microsoft and a board member of Darwin Molecular which is part of Gencell - seems not irrelevant to Gencell's apparent appeal. "The drug industry today is analogous to the microcomputer industry in the early 1970 s," says Gates in a statement circulated by Gencell. "We're doing what Bill did when he didn't have the money he has now," says Soursac.

Another concern is that RPR's 'toolbox' may be missing some essential spanners. "They have to make sure their joint ventures are leading edge," says one critic. "I would be more excited about this if I saw more big names." Soursac admits that Gencell may not have all the ingredients. "But we've got enough to cook dinner." Declan Butler

\section{Leonardo text yields a record price}

London. Leonardo da Vinci's 'Codex Hammer', a 72-page illustrated treatise on premodern science, was auctioned at Christie's, New York, last Friday for US\$30.8 million ( $\$ 19.2$ million) - the highest price ever paid for a manuscript.

Most of the book is devoted to Leonardo's original systematic observations and experiments on the properties and nature of water, which he links to speculations about cosmology, astronomy, tidal theory, meteorology, geology, physical geography and palaeontology.

He incorrectly supposes that sunlight reflected from the "waters" of the Moon is the source of moonlight. But he correctly deduces - as shown in a close-up of the new Moon (see right) - that the secondary light of the Moon is a reflection of sunlight from the oceans of the Earth (the Moon's lit area is shaded).

Leonardo also studies how a stream flows round an obstruction, offers practical advice on flood control, dams and canalization and presents engineering designs for the snorkel and submarine.

Compiled between 1506 and 1508 , the 'Codex Hammer' is named after its previous owner, Armand Hammer, the late American oil tycoon and art collector, who bought it in 1980 for $£ 2.42$ million from Viscount Coke, eldest son of the sixth Earl of Leicester. Thomas Coke, the first earl, acquired it in Florence in $\mathbf{1 7 1 7 .}$

The new buyer is computer entrepreneur Bill Gates, chairman of Microsoft Corporation. He intends to place the work, presumably to be renamed the 'Codex Gates' or 'Codex Microsoft' on public display, starting with a tour of Italian museums.

Peter Tallack

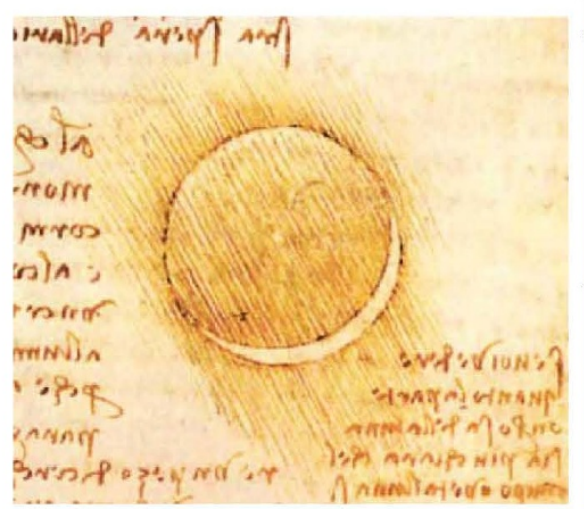

